\title{
Corporate Aesthetics and Communication in the Urban Arts and Visual Culture of Kumasi
}

\author{
A. E. Asante ${ }^{1}$, K. Opoku-Bonsu ${ }^{2}$, A. K. Ebehiakeh ${ }^{1}$ \\ ${ }^{1}$ Department of Educational Innovations in Science and Technology, KNUST, Kumasi, Ghana \\ ${ }^{2}$ Department of Painting and Sculpture, KNUST, Kumasi, Ghana \\ Correspondence: A. E. Asante, ${ }^{1}$ Department of Educational Innovations in Science and Technology, KNUST, \\ Kumasi, Ghana.
}

Received: May 10, 2020

Accepted: June 16, 2020

Online Published: July 16, 2020

doi:10.11114/smc.v8i2.4932

URL: https://doi.org/10.11114/smc.v8i2.4932

\begin{abstract}
Kumasi is the capital city of the Asante Kingdom of Ghana. Being the seat of the throne of the Asantehene, the King of Asante's, Kumasi is widely acknowledged as the major cultural city of Ghana. A study of the history of the people of Kumasi reveals that culture and art permeates their everyday life. Scholars have done some studies on the arts and economics of Asante and how it reflects their cultural life. However, a scholarly analysis of how corporate aesthetics is reflected in the urban art and visual culture of Kumasi has not been explored. In the bid to achieve this main objective, the paper discusses the corporate identities and cultural transformations in Kumasi, billboards, corporate commerce and savings, consuming visual culture and family finance and urban fantasies. The study is qualitative in nature and employs the descriptive method to provide an accurate description of specific urban arts in Kumasi.
\end{abstract}

Keywords: corporate aesthetics, visual culture, Kumasi, urban art, Ghana

\section{Introduction}

This paper examines the influence of corporate aesthetics on urban arts in Kumasi, Ashanti region of Ghana (Jamieson 2009; Radar 2010; Ramesar 1997). Kumasi is widely acknowledged as the major cultural city of Ghana and a study of its people and history reveals that culture and art permeates everyday life of the people. Scholars have studied on how arts and economics impacts the socio-cultural life of the people in the city but there is so far limited academic exploration of how corporate aesthetics plays into the visual culture (Mirzoeff 2006) and arts found in Kumasi and its relationship with the cultural demands of the metropolis (Bowditch 1966; Kwami 2013; Rattray; 1927).

Fifty years ago, the visual culture of Ghana was permeated by the works of 'sign writers (or 'wayside artists', as they are locally and popularly known). These were mainly talented artists with no formal education who developed their artistic practice through apprenticeship (Kwami 2013; 2001). Sign writers were responsible for advertisement and communication in the country and produced commercial signs for shops, electoral posters, paintings portraying beautiful African women, traditional landscapes, and in one recognizable genre, billboard posters for foreign films and cinema (Kwami 2013, p63). The main focus of these artworks was to mostly engender communication in the community where they were located (Jacob et.al 1995). Andrzejewski (2017), asserts that people however appear not to be able to differentiate the urban art object from the place or space in which it is located: people appear to find it easier to talk about 'places' rather than public art', using the language of the 'everyday'.

The Asantes are well known for their expertise in a wide range of specialized arts and crafts, which include sculpture made from (brass, gold weights and wood), textile production (Kente weaving and Adinkra printing and similar practices), pottery, metal smith and casting. Also, despite colonial incursion and postcolonial turmoil, Asante cultural and social structures have been preserved and maintained to the present day (Guerts 2009; Measah 2014b). In the early 1960s, different urban art forms emerged that narrated historical events and dictated a trajectory for visual culture of the society. Most of these historical works were located in public places and were commisioned by city administration, as well as members of the royal court to promote the culture of the 
people (Asante, Kquofi \& Larbi 2015). Other urban artworks were commisioned by specific communities with approval from the royal court in memory of some illustrous citizens of the culture. The main reasons for making of these urban artworks were to educate society about various historical events, to encourage identification with indigenous Asante culture in each community and to enhance the traditional environment with culturally inspired art works. These works were done to assert cultural ownership of the otherwise colonial city planning of Kumasi after the Asante Restoration of 1935, and Independence of Ghana in 1957 (Mensah 2014a; 2014b; Scmidt 2005). It is through this programme, that most surviving public art (mainly sculpture) in Kumasi was made. But these are not necessarily urban art. They could be found publicly, anyhwhere, including periurban spaces and towns.

Generally speaking, "The term urban art implies a strong inter-relationship between art and the physical nature and cultural fabric of an urban site. Through urban art, people have an opportunity to share experiences, revive collective memory, re-envision the future and strengthen their sense of belonging" (TPL, 2002, p. 4). Urban art can therefore be defined as concentrations of different art forms in a particular urbanized area. The roles and significance of urban arts in a particular location suggests it can reinforce and highlight a city's historical roots, cultural heritage and contemporary traditions. Urban arts also enable a spiritual connection between the historical cultural heritage and the contemporary quotidian culture, and it can also promote reflection, inspiration and celebration (among others). Traditionally, Asante people use urban art to enhance the cultural identity of their cities and the ambience of cultural facilities, communication centres, infrastructure, communal spaces meeting places, festivals and special events.

By definition, urban art is deployed in shared outdoor spaces thus making its public content an essential element of the work (Jamieson, 2009). Remesar (1997) argues that, the meaning of urban or public art can be measured and analysed through its wholeness, materials and fitness to the context which could also be interpreted as the aesthetic appeal. Public art practitioners have tended to be cautious about its evaluation; there is very little scholarly evaluation of urban art in Kumasi. Radar (2010) described urban art as an independent form of popular public art that is best understood by seeing it in its location. Urban art is therefore an essential and interesting tool for communication that is better understood locally depending on specific artefacts, project and the cultural values of the community. Annabel (2007), suggests that urban art is a process of engaging artists' and crafts peoples' creative ideas to produce specially commissioned work for public space. It can encompass a wide variety of processes, art forms and materials, and may be permanent, temporary, process-based, collaborative or participative, without necessarily generating a physical outcome. Urban art works such as historical monuments, cultural symbols, billboards and murals have been used to promote the splendour of some local/traditional institutions and the Ghanaian culture in so many ways. Such works of art usually serve as a local medium of communication between the people and the environment.

Urban arts have economic functions. Artworks designed and produced for urban places revitalize neighbourhoods and promote economic prosperity (Costello 1998; SCDCAC 2001; Stanziola 1999; Walesh 2001). In Ghana, the promotion of economic prosperity through urban art happens especially when the art attracts tourist and sightseers. These tourists usually impact local economies through direct expenditure on their visits to the monuments, shopping, eating at local restaurants and/or staying at a hotel within the community. Guetzkow (2002) agrees that the funding brought into the community for arts events often have direct and indirect multiplier effects on the local economy.

Urban art may also serve to attract certain categories of residents to the community and possibly retain them in the community. Also business such as travel and tour agencies may site their firms in communities with notable urban art as a way to become more visible to their potential patrons. Cwi (1980) suggests that some urban arts also attract highly skilled, high-wage residents, who have a larger economic impact on the community. Businesses, especially those that employ highly trained mobile personnel, may consider the location of important urban art when making (re)location decisions since most works of this type occupy the busiest and most central regions of the city. Aesthetically, the presence of the urban arts improves the image of a community and may enhance the impact of tax incentives for business location decisions (Costello 1998: 147-9).

High concentrations of artists and/or high-skilled workers also produces agglomeration effects, where businesses especially those in the fast growing 'creative industries' (Walesh 2001) are drawn to an area because of the availability of creative talent and/or high-skilled workers, and vice versa. In fact, art has been cited as a key element of gentrification, given the role of creative personnel in transforming formerly blighted neighbourhoods in many parts of the global North, protocols keenly observed by civic planners looking to enhance the economic viability of African towns and communities. In this regard, Guetzkow (2002) affirms that the arts attract investments: by improving a community's image, people may feel more confident about investing in that and may be more likely to buy property in an area that they feel is "up-and coming" because of the presence of the 
arts. Equally, banks are more likely to lend to businesses in areas perceived as more secure and stable. In most cases, the monies people spend on an artefact in a community either as taxes or 'gate fees' often pays for other goods or services. As such, the money circulates within a locality or city (Galbraith 1975).

This study examines how cultural meaning and aesthetics are woven into the corporate world of the people of Kumasi and how this influence how Kumasi is received. The historical and contemporary narratives built up around such artefacts are also discussed. It focuses on selected urban artworks from the cluster of sculptures, billboards and posters ubiquitous in Kumasi, Ghana. Brewer (2000), and Cohen and Manio (1989) propose that descriptive research of this sort is concerned with conditions, practices, structures, differences or relationships that exist, opinions held, on-going processes or trends that are evident in particular objects in context. In this particular instance, analysis of urban artworks provides insights into the changing roles of visual culture in contemporary Africa.

\section{Corporate Kumasi}

Corporate aesthetics do not exist is a vacuum. Their presence in communities share space and place with other forms of socio-political constructions (history, architecture, sculpture, city planning, small-scale business signage, notices and performances) from which they withdraw and project their distinctive contributions to the overall physical culture of a place and its brand (Dumbrăveanua 2010; Markusen \& Gadwa 2010).

Mercantile is not new to Kumasi, so is advertisement of wares. In fact, events that followed the sack of Kumasi in 1874, and subsequent colonial modelling of Kumasi, only made its trading position stronger, though at the expense of indigenous people (Geurts 2009; Mensah 2014b: Schmidt 2005). The emergence of British companies and products during this period of occupation, especially in the early 1900s, only rivalled the city's pre-sacked era with different power relations (Bowditch 1966). This period, covering the first three decades of the C20th saw British and Indian companies building permanent structures with concrete embossments and other forms of advertisements in Kumasi's Central Business District (CBD) in Adum, and adjacent to the C18th market place, Kejetia. Companies like Basel Mission Trading Company (BMTC), G. B. Olivant, P. Z. Cussons, U. A. C., Kingsway Stores, Barclays, Bata, Gold Coast Post Office and Railway Corporation and a host of others dictated the fledging colonial urban Kumasi, amidst resilient indigenous participations as distinct and different aesthetic construction (Agbodeka 1992; Gannon 1983). With the expansion of Kumasi to include its mid C20th peri-urban rural communities, and the city reverting to indigenous management, Kumasi as a colonial bequest underwent a massive re-indigenization, to resemble traditional African city with European traces (Mensah 2014a; 2014b).

In identifying contemporary corporate aesthetics within urban art in Kumasi, the paper reviewed the cultural practices that have earned Kumasi its reputation and place as a major trading centre from the C18th. These practices predate the subject this paper engages, but forms the foundations and part of the contemporary, since the traits of the indigenous in the urbanized Kumasi is characteristically stronger, than it is usual in most urban centres (Mensah 2014b: Schmidt 2005). This may be because Kumasi and Asante themselves are a modern culture within the wider scheme of things.

The economy of Kumasi from which the corporate representations are gleaned, is characterized by the amalgamation of corporate cultures within and out with West Africa. There are cultures which have been assimilated and others that have remained distinct, living and trading within Kumasi. These groups are the vessels that construct corporate aesthetics in their specific trades and transactions. At the basic levels, belief, ethnicity and perceptions play significant roles in their aesthetic constructions (Dumbrăveanua 2010). For instance, Kumasi's demography has always included other ethnicities from as early as the C18th. There are categories of Kumasi's residents, apart from indigenous Asante's, that are settlers from other parts of Ghana, while others are from other parts of the world, especially West Africa. The Akan speaking peoples are usually integrated, or mistaken as Asantes, and therefore share similar traits and values. The Ghanaian category, which are mainly coastal and savannah peoples, can professionally be broken into three main groups; artisanal, culinary, and mercantile. The coastal are Voltarians, Gas and Fantes, mainly Christian, and engaging distinctly in specialized professions, e.g. carpentry, bakery and indigenous catering forms. These groups advertise in vernacular, with various coastal and ethnic symbolisms. The savannah peoples are from the various ethnicities of Northern Ghana, and are mainly Muslims with mechanical, haulage, mercantile and culinary backgrounds. These categories of established professions are corporate identities and vehicles that dictate forms of corporate representation usually in Arabic and Hausa, with Islamic symbolisms. These groups occasionally come with indigenous religious practices distinct from Christian or Islam, and are usually advertised as trade.

Traditionally, these are small holding sheds, kiosks and shops, commuter buses and transports, long distant buses and haulage trucks on which advertisements with the above stated languages, including German, Korean and 
Mandarin (Chinese) in the recent El Dorado, as corporate identities. The Asantes themselves, traditionally also participate in these professions among many others, hence the phenomena above have their Asante equivalents as equal contributors in the aesthetics of urbanized Kumasi. Medium scale businesses with branches and numbers within Kumasi brand for easy identification, hence some serialities similar to corporate and multinational organizations, and major franchises.

Along the above are large scale corporations, international and huge multinational companies operating branches or headquartered in Kumasi, providing goods and services in the financial, hospitality, health, transportation, haulage and education, and others set in diplomatic engagements. These, together with Ghanaian and indigenous Asante companies, merchants and professionals determine Kumasi's corporate aesthetics within urban art with their needs to communicate and sell.

There is also the other side of corporate aesthetics in the urban art that enables multidimensionality of the aesthetic appreciation. This is the aural and performative components of the visual representations, usually with outreach and distribution channels. These forms are generally modelled on indigenous, cosmopolitan, or global forms with televised or radio versions, without which, the entire aesthetic deployment would be a silent movie experience. In all these, there is cultural symbiosis within the aesthetic realms of corporate identities, with indigenous and local businesses adopting certain visual vocabulary from foreign, international and multinational businesses, while the later adapting indigenous aesthetics to ground their trades (Baeyens 2012). This therefore differ from corporate aesthetics in other parts of the world, even with same company with branches in different parts of Ghana.

\section{Methodology}

Kumasi, capital of the Ashanti Region and the second largest city in Ghana, is known for its unique cultural heritage. The city is still "ruled" by the Asantehene (Asante King), Otumfuo Osei Tutu II, paramount ruler of Asante peoples, and the apex royalty in a hierarchy of confederate kingdoms of the former Asante Empire (1701-1895).

The visual outlook of the city of Kumasi represents the unique and rich culture of the region, and in the late 1960s almost all the urban artworks mounted in public places revealed the cultural life of the Asantes in one way or the other. In recent times, the demands of patrons of the urban art forms and the dynamics of global exchanges and economics are gradually driving the production of urban artefacts that are virtually universal. In other words, artists (including advertising houses) in the current dispensation do not place emphasis on the indigenous significance of their works, because most of their patrons are from corporate organizations instead of the royal court or indigenous patrons (Mirzoeff 2006; 1999; Rose 2001). This may also be, apart from the change in patronage, as a result of the multicultural demography of the artist, as well as heterogeneity of the city's cultural dispensation presently. In every way, the dynamics of commissions and omissions seem to oblige artists' practices, and are usually not given the opportunity to incorporate ethnic concepts of locations as before. It can therefore be stated that the universality of the corporate is substantially influencing the urban landscape of the Kumasi metropolis. These would form the bases of interpretation of the Kumasi urban aesthetics.

The study takes particular interest in Kumasi's as a case study with the intention to track inherent patterns of relationships between the visual culture, specifically visual communication in posters and billboards, and cultural memory within urban arts of Kumasi. Authors' preference for case study for corporate aesthetics in Kumasi stems from its reliability with regards to the present discussion, relevance to theory building, and providing multiples of meanings that bridge potential gaps between qualitative and deductive evidences (Becker \& Niehaves 2007; Eisenhardt \& Graebner 2007). The study is also based on Grounded Theory as a buffer for the case study method, because of its theoretical and social implications, and relies on historical references and cultural inferences to track the perceived aesthetic bending (Andrade 2009; Goulding 1998). It relies significantly on authors' ethnological understanding of Kumasi to navigate privileged literature and the overarching unintentional corporate place branding phenomena (Dumbrăveanua 2010; Hartel \& Thomson 2011). In effect, the study employs case study for design, and grounded theory for analysing its phenomena (Andrade 2009). The study also explores interpretivist approach, interpreting interpreted phenomena in visual communication (Goulding 1998; Hartel \& Thomson 2011) to unearth meaning constructions that both ground the indigenous and cosmopolitan, and also modify them. Authors' attempt a review of urban arts in Kumasi, with the view to see the impact of corporate aesthetics influences in Kumasi, potential city and cultural planning in health and service, and branding in the creative cities agenda (Dumbrăveanua 2010; Markusen \& Gadwa 2010; Morrisona, \& Dearden, 2013).

Authors observed artistic representations in Kumasi, vis a vis advertisement and signage, sponsorship announcements, and other notices of aesthetic significances (McNiff 2008, p29) by cultural inference 
(Sandelowski 2000; 1991). These, together with traditional public artistic representations constitute one aspect of the city's aesthetic appeal outside its architectural and planning, and sanitation with possibilities in qualitative research (Elliot \& Ladislav 2005). This aspect of the city's aesthetic representation contribute to the urbanized indigenous city's evolution worthy of investigation (Lambert and Lambert 2012; Elliot and ladislav 2005). Contemporary corporate participation in the affairs of the city is reminding of contributions of indigenous crafts and businesses in the agrarian and early modern economies, providing opportunities for inhabitants and visitors, and also reaping the benefits of patronages, especially in calendared festivals. Hence their presences in Kumasi suggest an evolutionary process with a modern twist (Illeris and Arvedsen 2011, p45-6), participating culturally in daily and epochal life of the city, and providing general and periodic aesthetic differentiations relevant to the times (Mirzoeff 2006; Rose 2001).

The study is grounded in Nicholas Mirzoeff's corpus of work (Mirzoeff 2011; 2006; 1999; 1998) in interpreting these carriers of urban aesthetics as visual stills, and possible precursors of the prevailing media proliferations in Ghanaian visual culture (Mirzoeff 1999). It explores the indistinguishability of vision and visuality as sensory and cultural dispensations respectively, relying on the other for legitimation (Mirzoeff 2006; Rose 2001), and draw syntheses between the prevalent visions, and visuality informed by cultural memory in Kumasi's urban aesthetics (Sandelowski 1999). Mirzoeff (1999) argues that the traditional imagery that informed the aesthetics under discussion is oblivious of its exterior realities. It is the hope that, by arguing on how the local modifies the universal corporate imagery (1998, p282-7) we will nudge the argument to modification. The study also explores Mirzoeff's inverse visuality, i.e. the possibility and necessity to explore the counterpoints between prevalent visualities and their other visualities as cultural play, the politics of the local exacting its weight on the universal (Illeris and Arvedsen 2011, p46), and veiled visualities where the universal disguises itself as local, culturally (Mirzoeff 2006, p70-6), as well as countervisuality as cultural practice in visual culture (2011, p282).

The study explored definitions by Radar (2010), Jamieson (2009) and Ramesar (1997), describing urban art generally as measurable contextual materiality and aesthetic construct for specific urban vicinity. Radar (2010) and Annabel (2007) argue popularity and artistic engagements of artisanal interpretations of specific localities and their concomitant artefactual representations as urban art irrespective of the genre. This study was mindful of the broad nature of the term's usage, thus limits it focus to the visual aspects of urban arts with hope of making meaning of their contextual phenomena (Lambert and Lambert 2012; Williams 2007; Kelley, Clark, Brown and Sitzia 2003). It sought to describe a prevailing phenomenon within certain cultural dispensation (Sandelowski 1991), in the bid to understanding how the universal is modified locally (Williams 2007).

\section{Corporate Identity and Cultural Transformations in the Urban Arts in Kumasi}

The art along the streets of Kumasi are imbued with historical and social content of importance to the Asante people (Kwami 2001). John Picton confirms that, the life of the street of Kumasi is enriched by the colourful signs, figures, clothing and royal palms (cited in Kwami, 2001). In Kumasi, most of the urban art pieces, such as posters and sculptures, can be found in the traffic circles and parks. Some of the posters and billboards located in Kumasi undoubtedly portray immense cultural elements, which speaks to Asante art, values and norms, even as they advertise services for corporations. They show how Asante peoples deploy indigenous values within a rapidly corporatized and globalizing urban context. A typical example is the poster that portrays an Asante woman and her daughter, dressed in a beautiful traditional clothes and cashing money via an Automated Teller Machine (ATM) (Figure 1). The poster's corporate message is stated in the graphics on its left side urging people to deposit their money with Barclays Bank and touting the ease and convenience of automated financial transactions. In Kumasi, graphic artists generate substantial income by producing similar designs for banks and other financial institutions. 


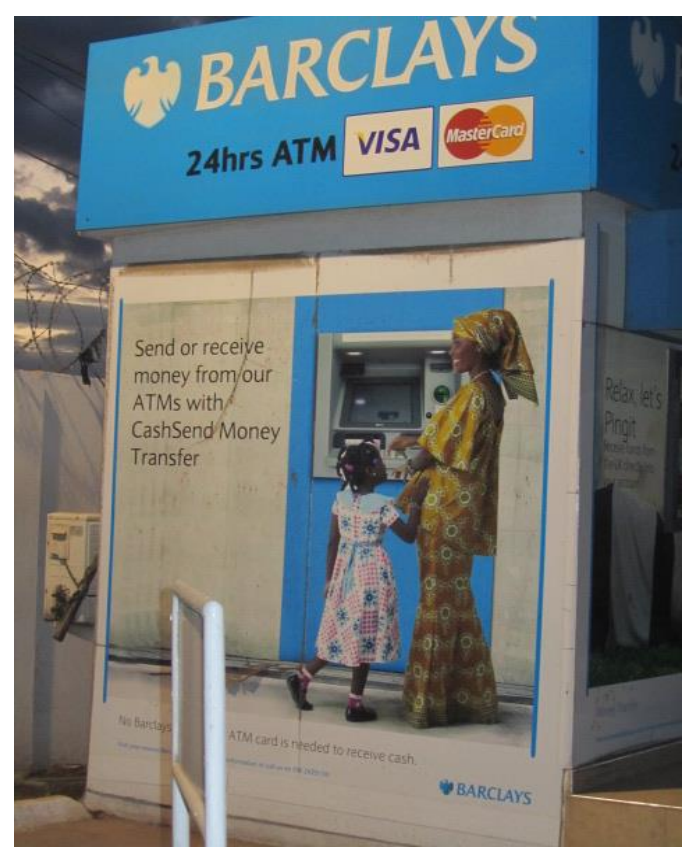

Figure 1. Poster at a Barclays Bank ATM

Artist: Unknown

Source: Researchers

Location: Kaase, Kumasi

Apart from the direct advertisement for financial transactions evident in this poster, other references to money are coded in the elements of its design. For example, it is fascinating to note that the artists of the Barclays Bank ATM Poster did not only seek to advertise the bank (Barclays) but also sought to portray beauty and the wealth of cultural adornment in the cloth of the Asante woman. For all of their history, Asante peoples have used textiles and other body adornment to narrate their wealth, gender and occupation. Asante textiles are therefore world famous, and this include some unique cultural products (Kente, is an example) that have become icons of black global identity

The woman in the poster wears a flamboyant scarf as part of her dress ensemble. Quaicoe-Duho and Appiah (2014) have stated that the wearing of scarfs by women is an old tradition among African women who deploy their scarfs and headgears as essential aspects of beauty. Specific headgear can indicate a woman's marital status and well-to-do married Asante women often use headgears made from the same clothes they wear. Since these attires require large quantities of cloth and reflect the fact that such women have the resources and wealth to buy enough yards of cloth to create their stylish attires. In terms of image symbolism, the Asante woman represented at the ATM in the poster shows her financial and cultural standing by the juxtaposition of local cloth and global finance. The golden yellow colour used for the background of the woman's cloth is another element in the design of the poster that directly reference money. In Ghana, the colour yellow is associated with wealth, and related to the rich gold deposits in the region from which both royalty and common people drew their wealth (Bortoli \& Maroto, 2001).

\section{Billboards, Corporate Commerce and Savings}

Billboards are common forms of communication in Kumasi and are visually rousing mediums for commercial advertisements designed to forcefully insert corporate messages into the public domain. The Bank of Africa billboard illustrated here (Figure 2) serves this purpose by advertising the bank's services to members of the community. Though simple in its design, the beauty is this billboard is that it invokes the urge to save money for future use. The design achieves this goal this by using the image of an empty money wallet, which suggests poverty. It is interesting to note that this billboard is strategically located at a generally impoverished part of Kumasi, a vicinity noted to be quite poor despite its nearness to the Kumasi airport where business are expected to flourish. Mustafa, Sukran and Olgun (2010) states that the primary objective of corporate establishments is to achieve institutional goals through the most efficient utilization of physical and human resources. Nyarko (2013) equally suggests that billboard advertisements can raise awareness of a company and increasing its customer base, thereby generating more income for the bank through the introduction of new customers. In this regard, the Bank 
of Africa billboard plays a dual role of soliciting income for the bank, as it generated income for the artist who made it. It also offers ideas to the community about generating income by saving.

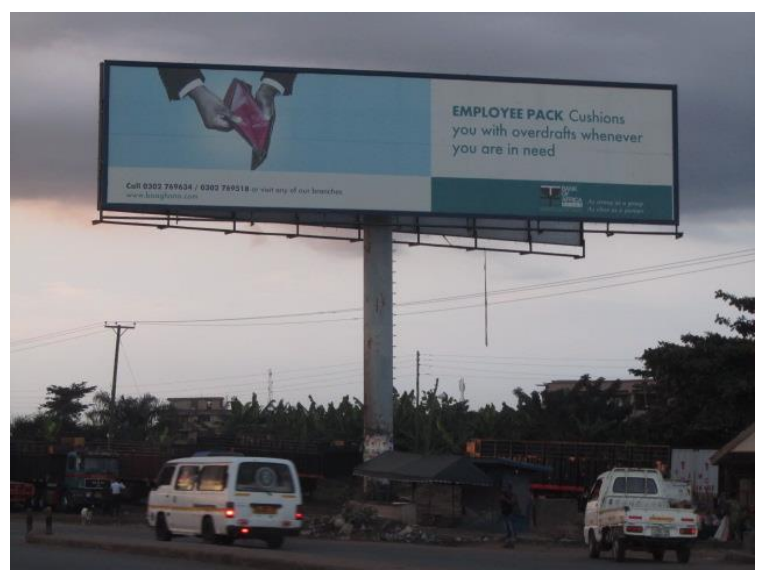

Figure 2. Billboard (Bank of Africa)

Artist: Unknown

Source: Researchers

Location: Kumasi Airport 'Roundabout'

Ghana has seen a recent rise in savings and loans companies since 2003 (Mensah, 2009). These companies also beautifully advertise their products and services to consumers in the areas where they are located through billboards such as those belonging to the First Allied Savings and Loans Company (Figure 3). This billboard is located at the Anloga Junction, at an intersection of roads leading to the Kumasi airport, Accra and other towns and cities. The location of the art is usually bustling with financial activities by individuals from all corners of the region who do business in the area. This makes the position of the billboard relevant and suitable for advertising the company's products and services which underscores African aesthetics as explained by Asmah, Asante and Okpattah (2015).
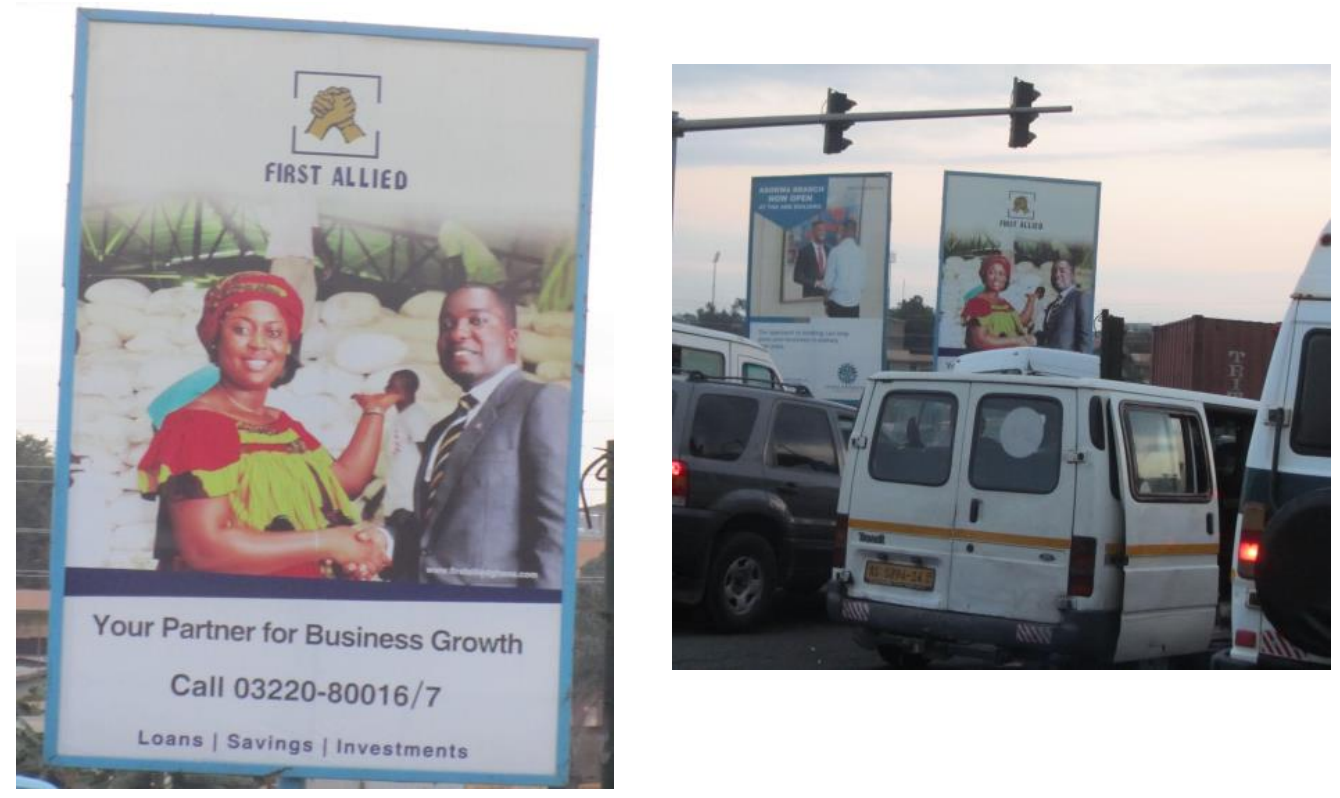

Figure 3. Billboard (First Allied Savings and Loans Company)

Artist: Mr. Samuel Addo

Source: Researchers

Location: Anloga Junction, Kumasi 
The poster uses selected images of a homely woman and man in the appropriate corporate attire to inform consumers about the products and services of the First Allied Savings and Loans Company. The key component of this poster is a woman who is successfully expanding her business after receiving a loan from this company. The artist portrays this by showing goods indicative of a flourishing business in the background of the image. The target group of this message varies from middle-income and low-income consumers. According to residents and labourers located in businesses around Anloga junction, members of the various Savings and Loans companies move from place to place (in Anloga) during the day to take contributions from them and deposit these in accounts in these institutions. This is relevant because the nature of their work is such that most of them do not often have access to banks to save their monies.

Our earlier definition of the roles and significance of urban art shows that the beauty of such artworks is that they often highlight a city's historical roots and reinforce its cultural identity. The First Allied Savings and Loans Company billboard achieves its purpose by disseminating information and raising awareness of the company's products and financial services. The woman's adornments highlights her wealth in the context of the Asante culture and supports the artists' effort to depict her success, as a wealthy woman who does business with financial corporations, employs labour, and produces significant merchandise that she signals to in the background.

\section{Consuming Visual Culture}

In the context of this study, consuming visual culture refers to the eatable aspect of culture expressed in visual images. Signs and advertisements for small-scale businesses are a staple of urban arts in Kumasi, adorning barbershops, grocery stores, food-service shops and similar establishments throughout the city. Food restaurants or "chop bars" as they are popularly known, are places that sell mostly indigenous dishes. These eateries have also realized the need in using billboards, signboards and posters to boost their income by advertising and suggesting their products and services to their customers. These establishments have seen an upsurge in recent years, and provide customers with varying food choices by exploring local dishes from different parts of the country. Some of the dishes prepared by these local chop bars include fufu (prepared with boiled yam, cocoyam, cassava and/ or plantain) with different types of soup (groundnut soup and palm nut soup being dominant options), banku prepared with corn dough and cassava dough and also served with different types of soup; Tuo Zaafi, Konkonte with palm nut or groundnut soup, Omotuo (also known as "rice balls"), Etew, and "red red" (beans stew with ripe plantain) just to mention a few. In the Ashanti region, all of these eateries serve $f u f u$, which is the native dish of Asantes.

The signboard illustrated here (Figure 4) belongs to the "Nyame Nsa Wom" chop bar located in the Oforikrom vicinity, about a four minute drive from the entrance of the Kwame Nkrumah University of Science and Technology (KNUST). It visually depicts images of the different types of local dishes offered for sale at the eatery. The vivid and appealing nature of the dishes indicated on the board attracts customers and the artist took care to provide necessary details about the varying food choices. The meals were photographed in explicit detail in order to differentiate one from the other. The target group for this particular signboard is the general public and it has varying choices for consumers to select from.

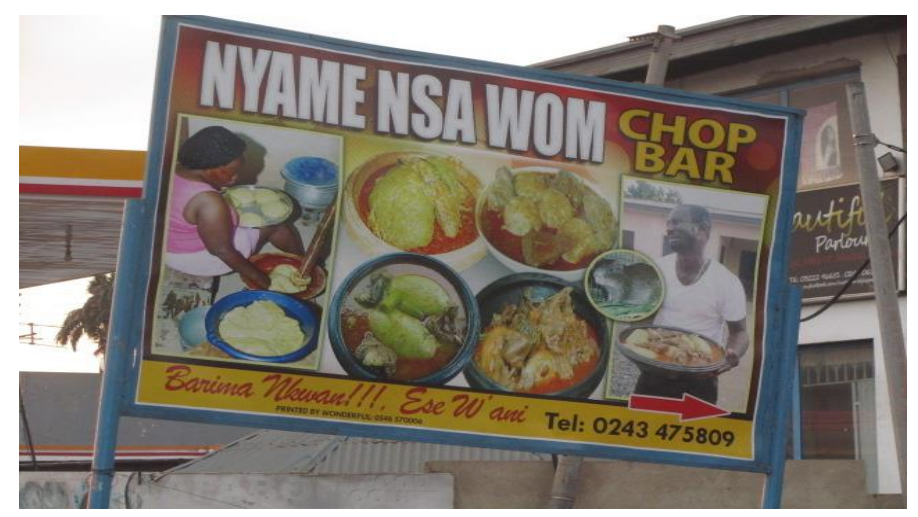

Figure 4. Signboard (Nyame Nsa Wom Chop Bar)

Artist: Unknown

Source: Researchers

Location: Oforikrom Transport (Gaao) 
In addition to images of the various types of dishes served at the "Nyame Nsa Wom" chop bar; a close look at the signboard shows a woman sitting on a traditional stool preparing fufu in a "wadro" or mortar. The wadro is a wooden mortar that derives its name from two Akan words: "wo" which means "has', and "adro" which means "medicine'. "Waduro" indicates that the wood used for making the mortar has medicinal properties (personal communication; Opanyin Yaw Yeboah, October 2015). Here, the beauty of this consuming visual culture lies in the implied meaning of the art. As propounded by the contextualist theory of beauty, it is thus believed that eating fufu prepared in the "wadro" gives the consumer renewed energy because of the medicinal properties of the wood that the mortar is carved from. The signboard's depiction of a woman preparing fufu in the wadro assures the customers that their food has been prepared in the traditional way. The signboard also shows a man holding an earthenware container with fufu and soup, which was used as a bowl for serving food by the Asantes. This billboard therefore uses culturally sanctioned images to signal the wholesome nature of the advertised eatery

Billboards, signboards and posters in Kumasi confer economic benefits through advertising and are intrinsic components of contemporary urban visual culture. Placement of such signage make strategic use of space and they are often located in places that generate lots of traffic. In this particular case, the affordable nature of local dishes means such food is accessible almost to every consumer. The signboard's celebration of local cuisine also celebrates an essential aspect of Asante culture, its love of food, thus sustaining a focus on tradition within the frenetic commercial context of the contemporary city.

\section{Family Finances and Urban Fantasies}

Billboards in Kumasi provide windows to urban aspirations, and often show desired outcomes rather than the lived experience of most urban dwellers. The beautiful, healthy and radiant figures in these billboards represent a fantasy of individual fulfilment and civic achievement often at odds with the hectic struggle for basic amenities of most urban dwellers. Nevertheless, these billboards persist in the message of a brighter future. Consider in this regard, the billboard for Advans Savings and Loans (Advans Ghana) advertising its financial services (Figure 5) located at Bomso junction near Kwame Nkrumah University of Science and Technology. The billboard informs consumers that depositing their money with Advans enrols them in a promotion from which they could win fabulous prices. The billboard shows a family and an individual who are both happy with the deposit and win promotion being run by the comnanv alongside details of nrices that will he given awav in the final draw, which include scholarships, airli

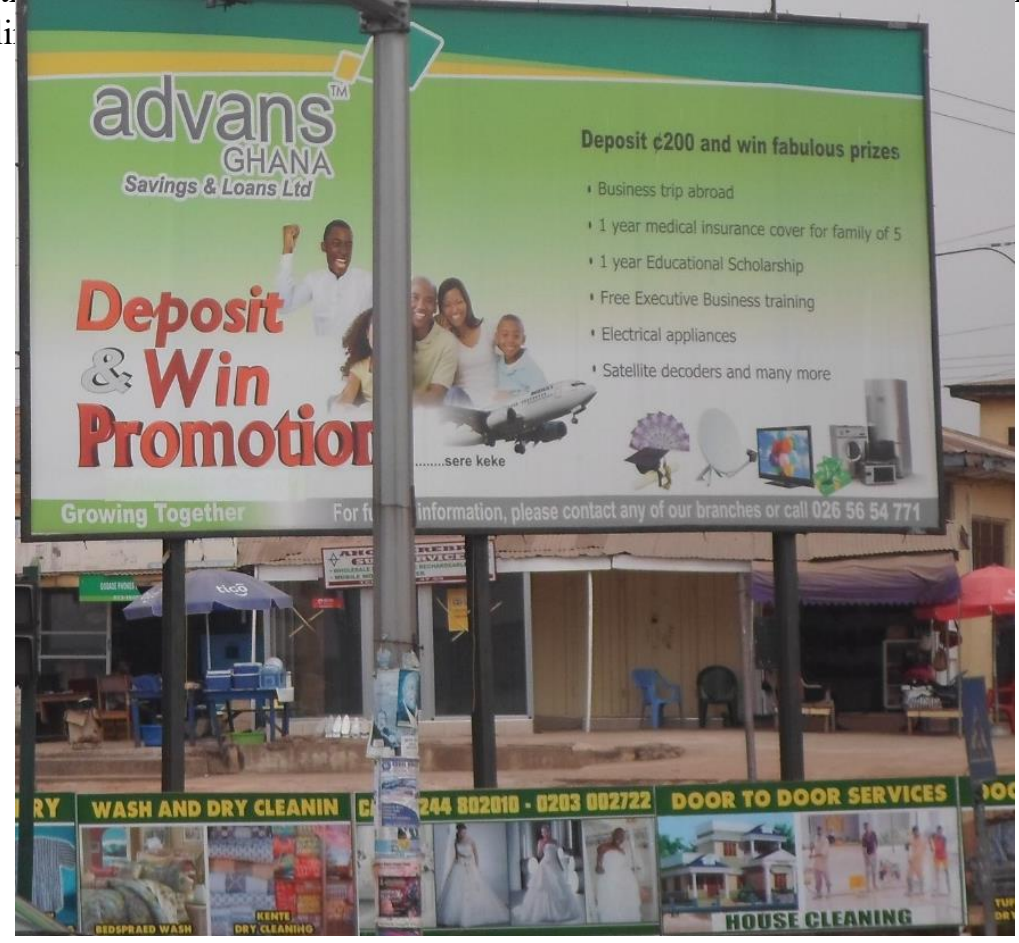

coverage.

Figure 5. Posters and bill board

Artist: Michael Ayettey

Source: Researchers

Location: Bomso Junction, Kumasi 
The ratio of expected deposit (200 cedis) to prospective awards clearly marks this promotion as less of a financial transaction and more of a lottery. The billboard sells a dream of economic fulfilment secured through prudent individual fiscal policy and outrageous luck, in an advertisement that appeals to a broad audience. The company tries to lure as many customers as possible into its promotion by suggesting that opening a savings account with it is the road to a better life. The economic focus and relentless modernity of this billboard resulted from direct specification of content by the savings and loans company. According to Ayettey, the artist who produced the billboard, the company rejected efforts to factor in design elements reminiscent of Asante culture.

This tension between the aesthetic impulses of artists and the inflexible advertising requirements of corporations challenges our earlier definition of the functions of urban art. Similarly, the tension between Asante cultural norms of personal decorum and contemporary social mores emerges clearly on some billboards. For example, a giant billboard located at Edward Nasser, Afful Nkwanta in Kumasi (Figure 6) shows a young man and woman in relatively amorous contact, both dressed in chic attire fashioned from local textiles. The man and a woman hold each other in an erotic manner above a caption that states they are "enjoying what they are wearing and having fun". If one of the purposes of urban art is to promote cultural character and identity, then one may question what kind of character such billboards signal to the people? What kind of message does it present? Is it on sex education, a generic display of culture or merely advertisement for locally made fabrics?

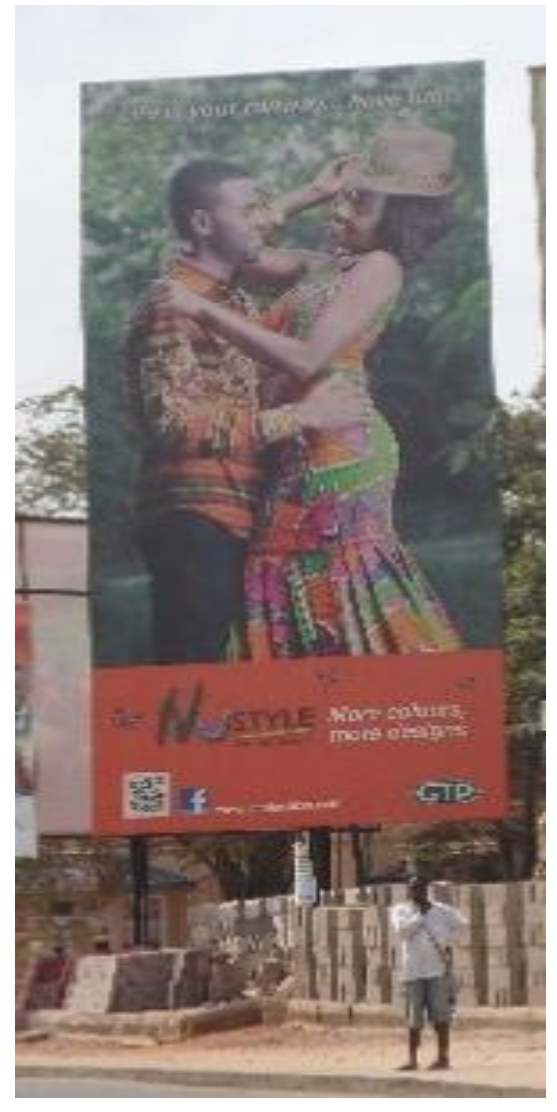

Figure 6. Bill Board showing a sensual posture

Artist: Mr. Roger Yebuah

\section{Source: Researchers}

\section{Location: Edward Nasser, off stadium road Kumasi}

This billboard belongs to Ghana Textiles Printing Company (GTP) and it uses Asante cultural values (again signalled through textiles) to promote the company's products with the ultimate aim of enhancing its financial profitability. GTP is one of the leading fabric producers in Ghana and it often undertakes rebranding of the fabrics that make up the five labels of the company (Tex Styles Ghana Limited, 2015). The billboard in question is a part of the rebranding of GTP's Nustyle fabrics and comprises one of about six such billboards that advertise Nustyle fabrics all over Ghana (R. Yebuah; Personal Communication, $18^{\text {th }}$ April, 2015). The image therefore depicts a male and a female clad in Ghanaian wax print fabrics made by GTP, hugging each other. 
The billboard's artist, Roger Yebuah, suggested that if he had his way, he would have created a different composition that speaks to the visual culture sensibilities of the community. However, GTP insisted on this particular concept and imagery with its modernist orientation and hints of glamorous urban engagements. Yebuah further stated that the creative opinions of billboard artists are usually not welcome in such situations and in this case, all he had to do was to bring the concept approved by GTP to life and get paid for his services. Here again, we see how basic financial exchange mediates the clash between corporate dictates and the creativity of Kumasi artists and leads to artworks that, despite its local referents, does not necessarily reflect the culture of the communities in which they are located.

\section{Conclusion}

Creative industries are growing in number and playing increasingly prominent aesthetic and cultural roles in the lives of many people across the globe. This phenomenon is also prevalent in Africa and especially in Ghana, evident in urban artworks, sculptures, posters, banners, billboards and murals displayed at various sites in the city of Kumasi. Many of these works, which are commissioned by the state, philanthropists, and the royal courts, are largely influenced by cultural sensibilities as a key variable, while also being influenced by the dictates of corporate financial institutions that serve as key patrons in the contemporary era. While urban arts commissioned by indigenous institutions and Asante communities highlight cultural motifs, urban arts commissioned by business organizations focus mostly on advertising their corporate wares. Despite this divergence, both types of urban art play crucial economic roles of generating income for artists and the community.

My analysis here exposes the steady drift of urban arts and patronage from culturally oriented to economically focused themes which presents their own aesthetic appeal as well. Rozin (2003) suggests that cultures operate to shape the environment, behaviour, and minds of their members. This implies a need for contemporary commentators to ensure that urban arts do not completely disregard the traditional ways of the people such art is targeted to. It is clear that corporate advertisements require a different focus and that they are often designed to enhance profits and generate new clientele.

\section{References}

Adam, A. (2017). Authenticity Manifested: Street Art and Artification, Rivista di estetica [Online], p $64 \mid 2017$, Online since 01 April 2017, connection on 16 November 2018. DOI 10.4000/estetica.2077

Aileen, T. L. (2002) Guidelines for the assessment of billboards. A revenue estimate. Formal Issue Paper, State of California, p2.

Andrade, A. D. (2009). Interpretive Research Aiming at Theory Building: Adopting and Adapting the Case Study Design. The Qualitative Report, 14(1), 42-60. Retrieved from http://nsuworks.nova.edu/tqr/vol14/iss1/3

Annabel, J. A. (2007). Evaluation of Public Art: A Literature Review and Proposed Methodology. Annabel publications, 3.

Art Radar (2010, January 21). What is Street Art? Vandalism, Graffiti or Public Art. Retrieved December 4, 2014, from Art Radar artradarjournal.com/2010/01/21/what-is-street-art-vandalism-graffiti-or-public-art-part-i

Asamah, E. A., Asante A. E., \& Okpattah (2015). Technology Adaptation and Its Effect on Asante Traditional Textiles. International Journal or Innovative Research and Development, 4(11).

Baeyens, A. (2012). Kumasi, Ghana. Critical Study of an African Urban Structure Kumasi, Ghana. Critical Study of an African Urban Structure.

Bortoli, M. D., \& Maroto, J. (2001). Colours across Cultures: Translating Colours in Interactive Marketing Communications. Proceedings of the European Languages and the Implementation of Communication and Information Technologies (Elicit) conference. University of Paisley.

Brewer, M. (2000). Research Design and Issues of Validity. In Reis, H. \& Judd, C. (eds) Handbook of Research Methods in Social and Personality Psychology. Cambridge: Cambridge University Press.

Bryan, J. (1998). The economic impact of the arts and cultural industries in Wales. Cardiff: Cardiff Business School.

Carducci, V. (2015). On Art and Gentrification. Temporary Art Review. http://temporaryartreview.com/on-art-and-gentrification/, accessed April 7, 2016

Cohen, L., \& Manion, L. (1989). Research Methods in Education. London: Routledge.

Cohen, R. (1994). Arts in the local economy: final report. Washington: National Assembly of Local Arts Agencies.

Costello, D. J. (1998). The Economic and Social Impact of the Arts on Urban and Community Development. A 
Dissertation Abstracts International, a: The Humanities and Social Sciences. Pittsburgh: University of Pittsburgh, 1333.

Culture and Commerce (2003). Traditional Arts in Economic Development. The Urban Institute/The Fund for Folk Culture www.tamu.edu/faculty/choudhury/culture.html

CWI D. (1980). The role of the arts in urban economic development. Washington, D.C.: Economic Research Division Economic Development Administration.

Dumbrăveanua, D. (2010). Place Branding: A Challenging Process for Bucharest the Capital City of Romania. Human Geographies - Journal of Studies and Research in Human Geography, 4(2), 53-62.

Eisenhardt, K. M., \& Graebner, M. E. (2007). Theory Building from Cases: Opportunities and Challenges. Academy of Management Journal, 50(1), 25-32. https://doi.org/10.5465/amj.2007.24160888

Elliott, R., \& Timulak, L. (2005). Descriptive and Interpretive Approaches to Qualitative Research. A Handbook of Research Methods for Clinical and Health Psychology. Jeremy Miles and Paul Gilbert (Ed.), New York, NY: Oxford University Press. http://nideffer.net/classes/GCT_RPI_S14/readings/interpretive.pdf

Eric, A. A., Steve, K., \& Stephen, L. (2015), The symbolic significance of motifs on selected Asante religious temples. Journal of Aesthetics \& Culture, 7(1). https://doi.org/10.3402/jac.v7.27006

Galbraith, J. K. (1975). Money, Whence It Came, Where It Went. Geraldine Perry \& Ken Fou Publication.

Goss, K. (2000). Better together: The report of the Saguaro Seminar on Civic Engagement in America. Cambridge, MA: Saguaro Seminar Civic Engagement in America John F. Kennedy School of Government Harvard University. http://www.bettertogether.org/bt\%5Freport.pdf.

Goulding, C. (1998). Grounded theory: the missing methodology on the interpretivist agenda. Qualitative Market Research: An International Journal, 1(1), 50-57. https://doi.org/10.1108/13522759810197587

Guetzkow, J. (2002). How the Arts Impact Communities: An introduction to the literature on arts impact studies. Taking the Measure of Culture Conference, Princeton University.

Hartel, J., \& Thomson L. (2011). Visual Approaches and Photography for the Study of Immediate Information Space. Journal of the American Society for Information Science and Technology, 1-11. https://doi.org/10.1002/asi.21618

Illeris, H., \& Arvedsen, K. (2011). Visual Phenomena and Visual Event-Some reflections around the curriculum of visual culture pedagogy. SYNNYT / Origins, (2), 44-63.

Jacob, M. J., Olson, E. M., \& Brenson, M. (1995). Culture in Action: A Public Art Program of Sculpture Chicago. Bay Press p144p ISBN 978-0-941920-31-5

Jamieson, R. (2009, April 29). Urban Art Should Stay on the Street. Retrieved December 4, 2014, from The Guardian: www.theguardian.com/artanddesign/2009/april/29/street-art-buyers

Kelley, K., Clark, B., Brown, V., Sitzia, J. (2003). Good practice in the conduct and reporting of survey research. International Journal for Quality in Health Care, 3(15), 261-266. https://doi.org/10.1093/intqhc/mzg031

Kwami, A. (2001) Kumasi Realism, 1951-2007 An African Modernism. http://www.ralphmag.org/HY/kumasi.html

Lambert, V. A., Lambert, C. E. (2012). Qualitative Descriptive Research: An Acceptable Design (Editorial). Pacific Rim International Journal of Nursing Research, $4(16), \quad 255-256$. http://www.tci-thaijo.org/index.php/PRIJNR/article/view/5805/5064

Markusen, A., \& Gadwa, A. (2010). Arts and Culture in Urban or Regional Planning: A Review and Research Agenda. Journal of Planning Education and Research, 29(3), 379-391. https://doi.org/10.1177/0739456X09354380

Matarasso, F. (1997). Use or ornament?: The social impact of participation in the Arts. Stroud, Glos.: Comedia.

McCaskie, T. C. (1995). State and society in pre-colonial Asante. Cambridge: Cambridge university press

McNiff, S. (2008). Art-Based Research. Handbook of the Arts in Qualitative Research: Perspectives, Methodologies, Examples, and Issues. J. Gary Knowles And Ardra L. Cole (Ed) p20-40. Thousand Oaks, CA: SAGE Publications Ltd.

Mensah, M. M. (2009). The Role and Challenges of Savings and Loans Companies in Ghana. School of Graduate Studies Kwame Nkrumah University of Science and Technology. Kumasi

Mirzoeff, N. (1998). Introduction to Part Four. Visual Culture Reader. Nicholas Mirzoeff (Ed). New York, NY: Routledge. 
Mirzoeff, N. (1999). What is Visual Culture? An Introduction to Visual Culture. New York, NY: Routledge.

Mirzoeff, N. (2006). On Visuality. Journal of visual culture, 5(1), 53-79. https://doi.org/10.1177/1470412906062285

Mirzoeff, N. (2011). The Right to Look. Critical Inquiry, 3(37), 473-496. https://doi.org/10.1086/659354

Morrisona, C., \& Dearden, A. (2013). Beyond tokenistic participation: Using representational artefacts to enable meaningful public participation in health service design. Health Policy, 112, 179-186. https://doi.org/10.1016/j.healthpol.2013.05.008

Mustafa, G., Sukran, K., \& Olgun, K. (2010). The Effects of Outdoor Advertisements on Consumers: A Case Study. Studies in Business and Economics, 2, 70-88.

Nyarko, I. K. (2013). Effects of Electronic commu Advertising on Rural Banking in Ghana: A Study of Unity Rural Bank Limited, Ho Ghana. Journal of Asian Business Strategy, 3(11), 315-329.

Nyarko, P. (2012). Ghana Statistical Service Releases Census Results. Ghana News Agency, June 1 release.

Opoku-Asare N. (2010). Indigenous Headgear of Asantes. Unpublished manuscript, Art Education p13.

Osei, K. (1994). An Outline of Asante History. Third Edition, pp6-11 Cita Press Ltd. Kumasi.

Policy Research Institute (2009). Evaluation of the Northern Way 'Welcome to the North' Public Art. Leeds Metropolitan University. p89.

Quaicoe-Duho, L., \& Appiah, S. (2014). Headscarf: African Woman's Crown of Beauty. Graphic Online. http://graphic.com.gh/lifestyle/fashion/27726-headscarf-african-woman-s-crown-of-beauty.html

Remesar, A. (1997) (ed) Urban Regeneration: A Challenge for Public Art. Unviersitat de Barcelona.

Rose, G. (2001). Visual Methodologies: An Introduction to the Interpretation of Visual Materials. Routledge, London

Rozin, P. (2003). Five potential principles for understanding. Philadelphia: Academic Press.

Sandelowski, M. (1991). Telling Stories: Narrative Approaches in Qualitative Research. Image (Journal of Nursing Scholarship), 3(23), 161-166. https://doi.org/10.1111/j.1547-5069.1991.tb00662.x

Sandelowski, M. (2000). Whatever Happened to Qualitative Description? Research in Nursing \& Health, (23), 334-340. https://doi.org/10.1002/1098-240X(200008)23:4<334::AID-NUR9>3.0.CO;2-G

SCDCAC (2001). The arts and culture in San Diego: economic impact report, 2000. San Diego, Calif.: City of San Diego Commission for Arts and Culture.

Sidford, H. (2000). Fusing Arts, Culture and Social Change: High Impact Strategies for Philanthropy. Shoulder To Shoulder City-Wide Youth Banner Project, 2000. In Partnership with Los Angeles Human Relations Commission, SPARC and UCLA.

Stanziola, J. (1999). Arts, government and community revitalization. Ashgate: Aldershot, U.K.; Brookfield, Vt. and Sydney.

Tex Styles Ghana Limited (2015). GTP, Labels. Retrieved from http://gtpfashion.com/

Torque Property Limited (2002). City of Port Phillip Urban Art Strategy. Department of Urban Design and Architecture. Retrieved from http://www.portphillip.vic.gov.au/Port_Phillip_Urban_Art_Strategy_2002_low_res.pdf

Urban Art Project Reference Group (2013). Art: www.busslton.wa.gov.au/sites/busselton.wa.gov.au/files/cp017-urban-art.pdf

Walesh, K., \& D. H. (2001). The Creative Community--Leveraging Creativity and Cultural Participation for Silicon Valley's Economic and Civic Future. San Jose, CA: Collaborative Economics.

Williams, C. (2007). Research Methods. Journal of Business \& Economic Research, 3(5), 65-72. https://doi.org/10.19030/jber.v5i3.2532

Williams, D. (1995). Creating social capital: a study of the long-term benefits from Community-based arts funding. Adelaide, S. Aust.: Community Arts Network of South Australia.

\section{Copyrights}

Copyright for this article is retained by the author(s), with first publication rights granted to the journal.

This is an open-access article distributed under the terms and conditions of the Creative Commons Attribution license which permits unrestricted use, distribution, and reproduction in any medium, provided the original work is properly cited. 